\title{
A Lunisolar Prehistoric Calendar in Lanzarote Island: "La Quesera" (Cheeseboard) from Zonzamas.
}

\author{
Marcial Medina, Antonio Arnaiz-Villena
}

\begin{abstract}
Department of Inmunology, University Complutense, School of Medicine, 28040 Madrid, Spain. MM address: Arrecife, Lanzarote 35500, Islas Canarias (Spain).E-mail: marcialmedina53@gmail.com Corresponding Author: Antonio Arnaiz-Villena. Departamento de Inmunology, Facultad de Medicina, Universidad Complutense, Pabellón 5, planta 4. Avd. Complutense s/n, 28040, Spain. E-mail: arnaizantonio@gmail.com Web page: http://chopo.pntic.mec.es/biolmol/
\end{abstract}

(Received 1 April 2018; Accepted 25 April 2018; Published 5 May 2018)

\begin{abstract}
Zonzamas "Quesera" (Zonzamas "Cheeseboard") is a lunisolar calendar according to evidences shown in the present paper. It represents Ancient Canarian Year ("Atxano", meaning "stick,axis or hill shadow"), which started at Summer Solstice, June $21^{\text {st }}$. Six carved channels -left to right- sequentially represent the first six Canarian months. The first carved channel shows: a) the first Old Canarian month starting June $21^{\text {st }}$ with 30 days; following channels were following five Ancient Canarian months and b) landscape as observed from Zonzamas "Quesera" that includes Maneje and Tahiche mountains (where sun rises June $21^{\text {st }}$ ) and part of coast and sea.Also, intermediate (between carved channels) basalt rock prominent strips (right to left) represent sequencially the second six Canarian months ,starting with Winter Solstice when it is the $7^{\text {th }}$ Ancient Canarian month. The 3rd rock strip (right-left direction) represents 9th Ancient Canarian month and has a conic salient, probably representing that a correction should be done in this month (February-March in Gregorian Calendar), for example, adding one day each four years (Leap Year). Thus, Zonzamas "Quesera" is a 365 year sun calendar according with our evidences, which also may take into account lunar month phases as it will be detailed in another forthcoming paper. Zonzamas "Quesera" is put in context of old "Guanche"/"Majo" aborigen culture which may go back according to archaeological findings to an Epoch of Atlantic/Mediterranean Bronze Age-Megalithic culture at least and before Punic or Roman culture reached Canary Islands.
\end{abstract}

Keywords: Zonzamas, Quesera, Lanzarote, Canary Islands, Anthropology, Prehistory, Genetics, Iberian Scripts, Calendar, Lunisolar, Sun, Moon, Achano, Archaeology, Berber, Roman, Punic. 


\section{Introduction}

The Canary Islands (Spain) are a group of 7 volcanic islands, between 100 and $500 \mathrm{~km}$ (62.13 and 310.68 miles respectively) far from North African Coast (Morocco).

The two easternmost islands, Fuerteventura and Lanzarote are 23 and 15 million years old respectively. Volcans are still active in the archipielago and in Lanzarote island Timanfaya eruption took place in this island 1730/1736 AD (Bogaard, 2013) (Fig. 1).

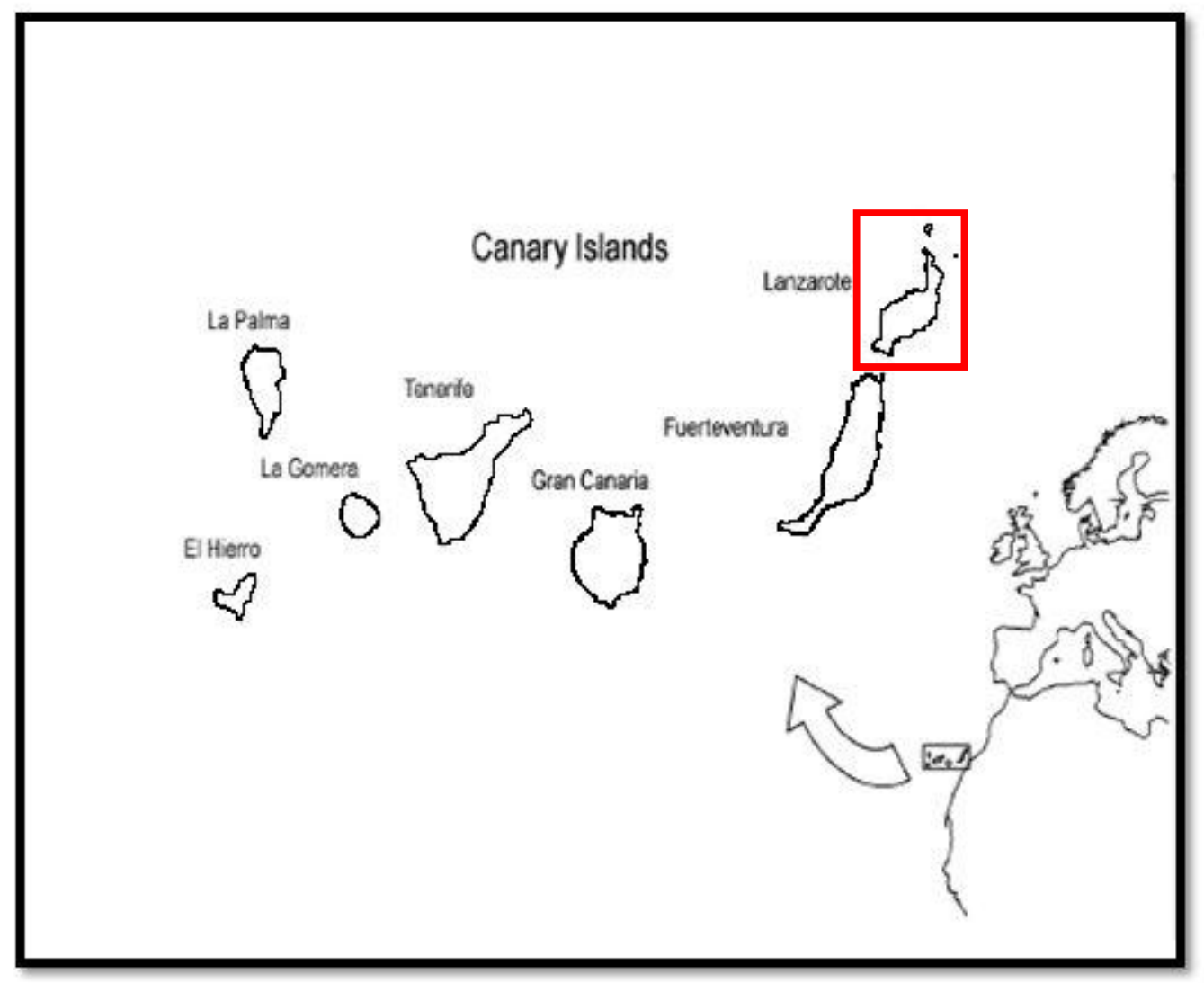

Fig. 1 Map of Canary Islands with their names and the Atlantic coast lines of Europe and North West Africa.

Lanzarote island is $125 \mathrm{~km}$ (78 miles) apart off African Coast. Present paper interest is on a prehistoric monument at Lanzarote (presented inside red square).

Extant old Atlantic prehistoric petrogliphs, momification, pyramids in Canary Islands and also megalithic buildings in the nearby African coast (125 km, 78 miles) off Lanzarote island suggest also a prehistoric islands population existence and culture (Braem, 2010 ; Fanjul Peraza, 2003 ; Arnaiz-Villena et al, 2015 ). This is supported by archaeological material found in Lanzarote as old $2^{\text {nd }} / 1^{\text {st }}$ millenium BC fron 43 different samples from different Lanzarote sites (Atoche Peña \& Ramirez Rodriguez, 2016). 
Also, recent ceramic studies from diverse Lanzarote placements show that ceramics is very similar to Bronze Age Megalithic Mediterranean/Atlantic culture, similar to that found in Huelva (Spain) and other Iberian Peninsula sites by $4^{\text {th }}$ millenium BC (Sluys vd \& Gonzalez Artabe, 2017).

Lanzarote is the first island that was conquered by Spanish Kings in 1402: Norman mercenaries Jean de Bethancourt and Gadifer de la Salle commanded an army and carried out this conquest. Lanzarote island aborigines ("Majos") were ruled by a single king: "Guadarfia", who lived in Zonzamas town, close to its nowadays capital, Arrecife. (Paz Sanchez \& Quintero Sanchez, 2008; Cabrera Perez, 1992). Zonzamas city ruins still stand and may be seen.

"Majo" or "Maho" is probably an aborigine word coming from Lanzarote and Fuerteventura Islands inhabitants that meant people that weared "primitive goat skin shoes tied with strings and streps" (Corrales \& Corbella, 2013).

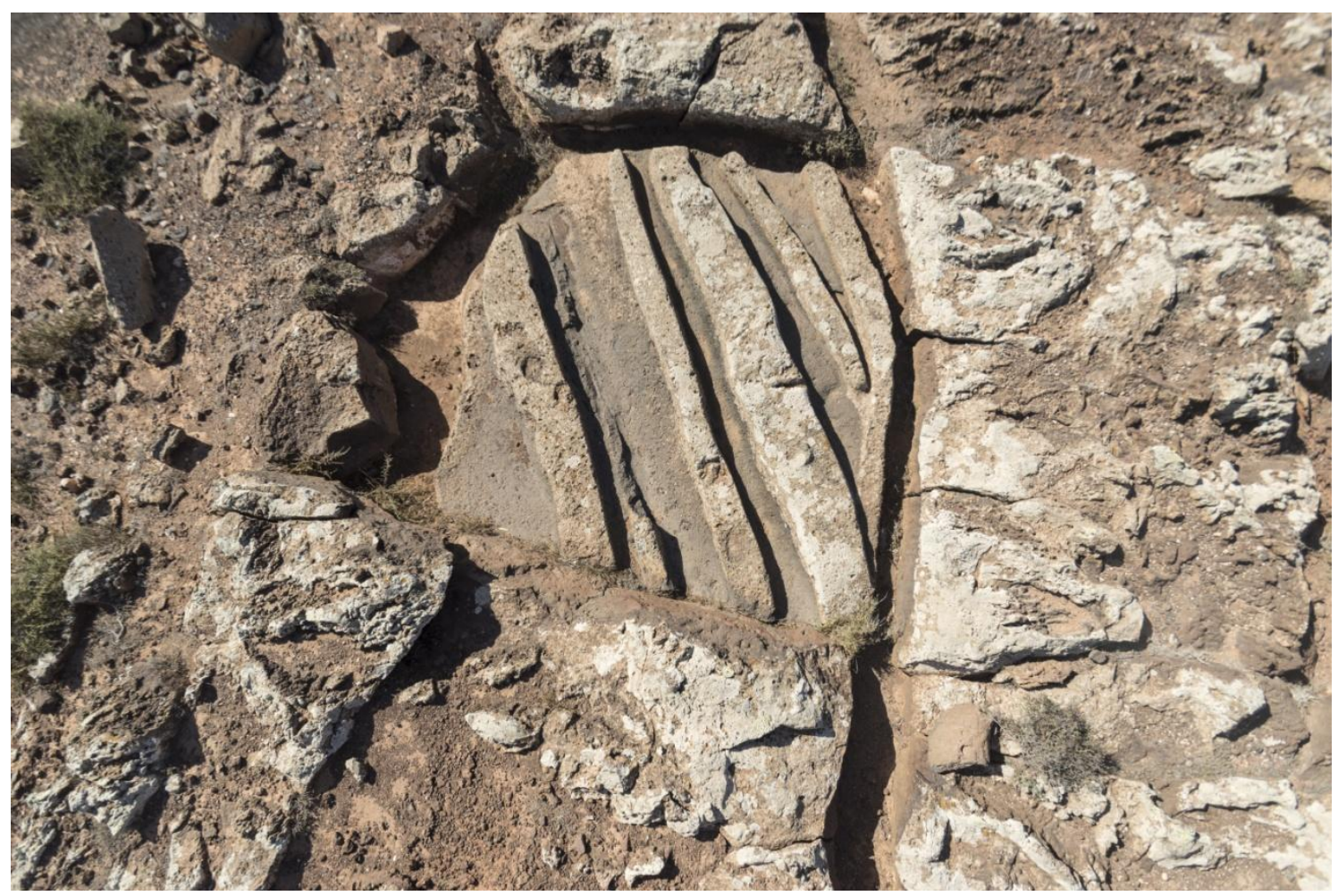

Fig. 2 "Quesera" (Cheeseboard) of Zonzamas

(29. $0005702^{\circ}$ North latitude and 13. $5677934^{\circ}$ West longitude). It consists of six grooves carved in basaltic rock, $30 \mathrm{~cm}$ high (11.8 inches) and between $27-45 \mathrm{~cm}$ wide (10.6 - 17.7 inches). Its largest diameter is 3.9 meters (127.9 feet) six/rock segments-strips were left prominent between carved channels. Podomorph rock engravings are recorded in other nearby places (Cabrera Perez, 1992). Its location lays on a hill close to ancient capital, Zonzamas; it has a wide view to present day Lanzarote capital, Arrecife. 


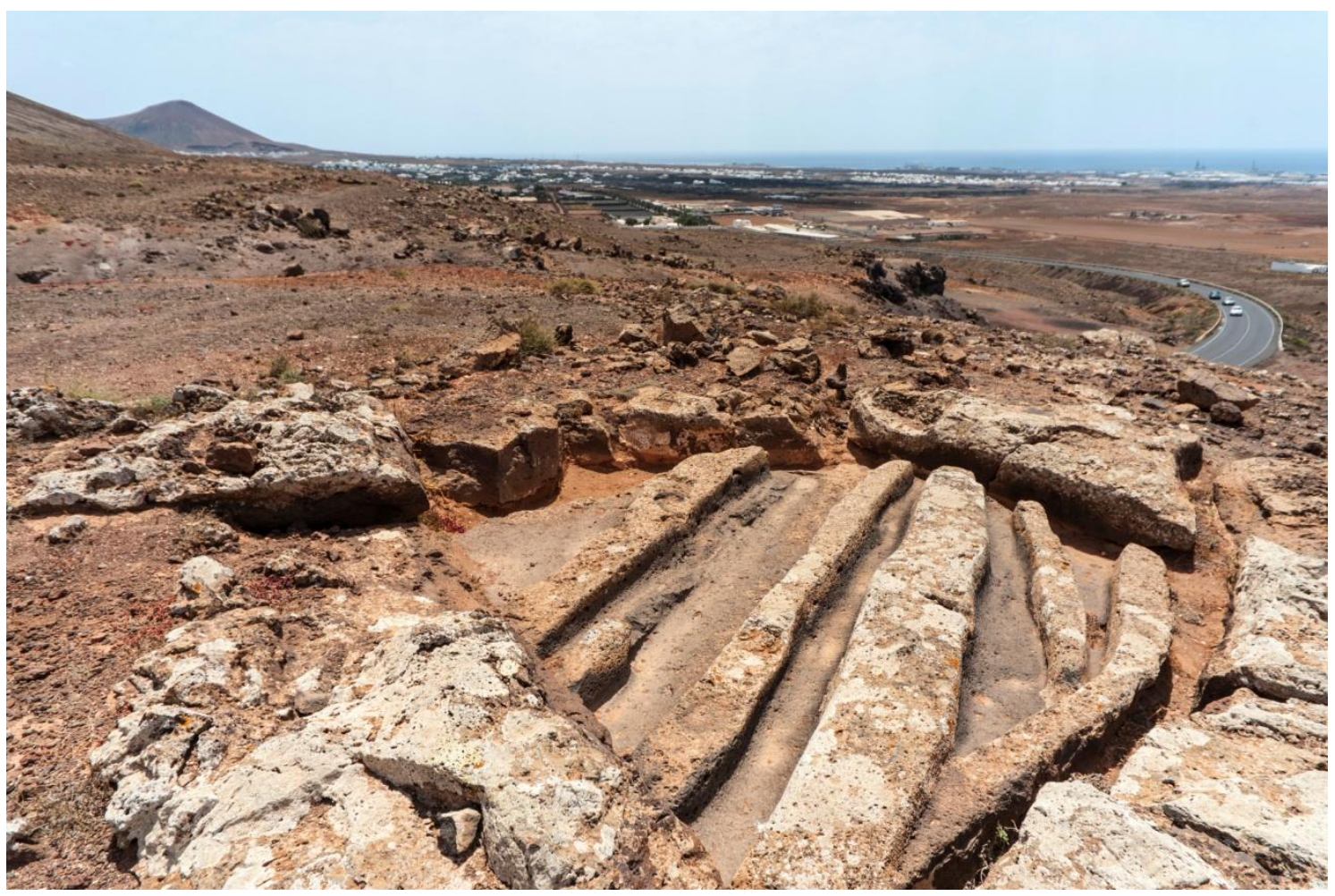

Fig. 3 A Southeast view from "Quesera" (Cheeseboard) of Zonzamas

It is 120 meters above sea level and it is seen a view of Maneje mountain (far left), Tahiche mountain (close and more central) and Teguise/Arrecife coast and sea towards right. Sun rises in Summer Solstice (June 21st) at Maneje/Tahiche mountains angle (see Fig. 4).

Several aborigine prehistoric artefacts have been found in Lanzarote of uncertain age, like ceramics and rock inscriptions, both showing in ancient berber / North African and ancient Iberian writing characters or Ibererian-“Guanche" scripts are engraved in many rocks (Arnaiz-Villena \& Alonso Garcia, 2001; Arnaiz-Villena et al, 2015). The "Queseras" (Cheeseboards) are prominent among these prehistoric artefacts. They have been named "Queseras" because of "Majo" aborigines made more or less parallel channel structures carved in basaltic rock (see Fig. 2 and 3 ), which vaguely resembled to "Cheeseboards".

Five "queseras" have at least been recorded in Lanzarote: Zonzamas (Fig. 2, 3, 7 and 8), Malpais of La Corona, close to Los Jameos del Agua (two): "Bravo" and "Nueva" quesera. Conservation of these two ones is poor. Another two ones have now been destroyed by accident because of new modern constructions or other causes (one was placed at San Bartolomé village and another one at Mina Mountain) 
(www.historiadeharia.com/PATRIMONIO/Datos/queseras-2-htm), (Cabrera Perez, 1992).

"Queseras" are prehistoric artefacts specific for Lanzarote Island within Canary Islands. Their posible religius/ritual meaning and usefulness have been debated but at present no conclusion has been reached. (Braun, 2010; Cabrera Perez, 1992).

In the present paper, we show evidences that "Quesera" de Zonzamas is a prehistoric calendar.

\section{Material and methods}

\section{Study}

One of the authors, Marcial Medina was born in Lanzarote and has lived close to "Quesera" of Zonzamas most of his life since age of seven years. He is a freelance archaeologist who has searched every Lanzarote's corner and has dsicovered many ancient rock engravings and other ceramic and archaeological tools.

He has spent many days and nights close to "La Quesera" and finally he has become aware that it could be a calendar used by ancient "Majos" from Lanzarote (today included within the generic name of "Guanches" in English literature for all Canary Islands prehistoric inhabitants).

$\mathrm{He}$ is a sailor and had knowledge of astronomic measurements. Thus, he took a simple compass (see below) and started to measuring sunrise azimuth and altitude (Magli, 2016) every day during a two years period (2014-2015) from the "Quesera" de Zorzamas elevation (162 meters, 629.92 feet above sea level) placed at $29.0005702^{\circ}$ North latitude and $1.5677934^{\circ}$ West longitude.

\section{Methods}

SPSMAP 60c color map Navigator was used for local coordenate assesment (Garmin International, Kansas, USA). Suunto Tandem/360PC/360R DG compass and clinometer (Turku, Finland) was used to record everyday azimuth and altitude during two years (2014 - 2015). Data were introduced in a computer program that calculated all other measurements from "Quesera" Zonzamas longitude / latitude location, (SunEarthTools.com, online program). Other instruments were used for reassessing measurements: above mentioned SPSMAP navigator and binoculars 7x50 Estancos Anti-Impactos with Plastimo Compass (Sea Binoculars, Plastino USA Inc, Wilmington, Delaware, USA). 


\section{Results}

Sunrise along ancient Canarian year (starting Summer solstice, June 21th) appears today in Maneje-Tahiche mountains angle (Fig. 4). Lines are depicted for easy comprehension for readers, but they do not represent any shadow corresponding to this "Quesera" calendar month strip (see below in Discussion section)

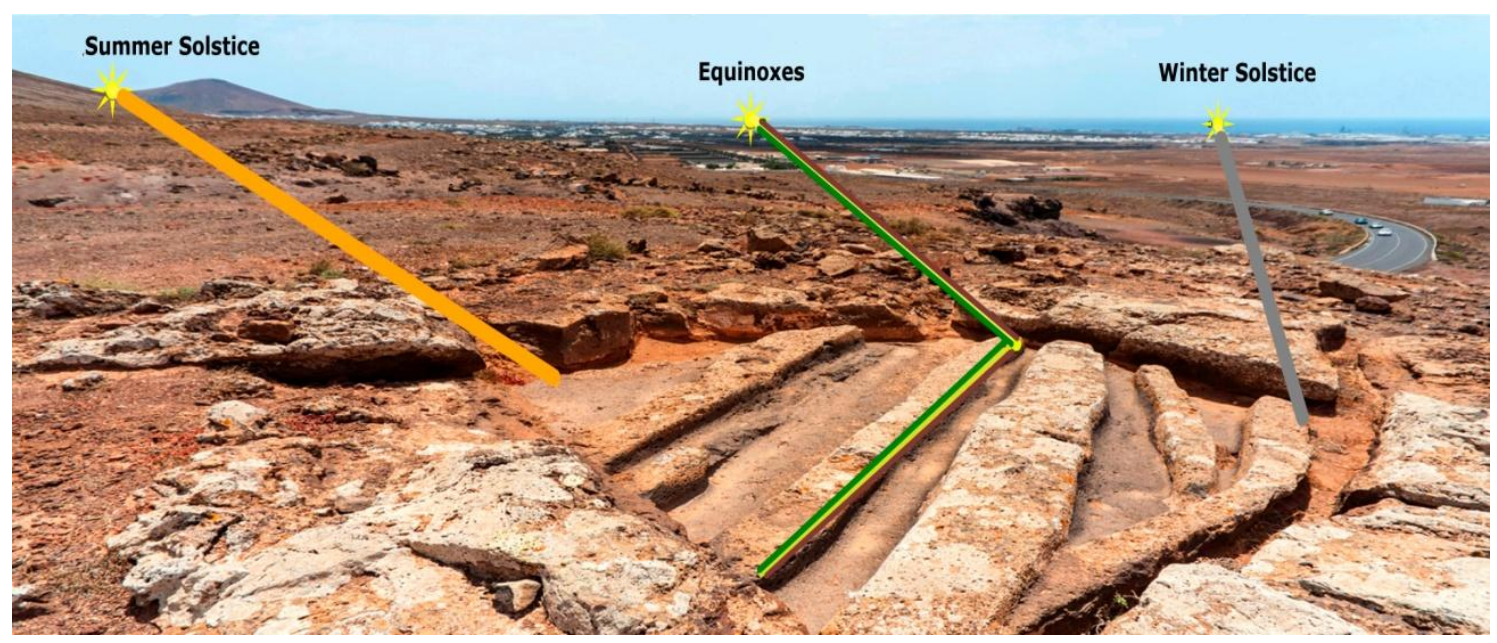

Fig. 4 Sunrise at Summer Solstices, Autumn/Spring Equinoxes and Winter Solstice from a "Quesera" observer (left to right). Photography from "Quesera" of Zonzamas.

Left: Sun rises (2014 AD) between Maneje and Tahiche mountains at Summer Solstice (orange line). It is possible that if "Quesera" is ancient enough, an observer from this point might have seen Sun rising at Tahiche mountain slope or vertex in Antiquity because Ecliptic obliquity is diminishing about 0.47 arch seconds per year at present times, (Magli, 2016). Middle: Sun rises at middle sea horizon, both at Autumn and Spring Equinoxes (green line).

Right: Sun rises at right sea horizon at Winter Solstice (grey line). Sunrises complete a yearly azimuth arch between $62^{\circ}$ and $117^{\circ}$ degrees going from June 21 st to December 21 st and back (Fig. 5, 6).

It was observed that first carved channel (Fig. 2, 7, 8) had a depicted contour resembling the Tahiche mountain silhouette, where Sun raised at the beginning of Canarian ancient year (Summer solstice) according to Marin de Cubas (1694) and other authors (Gomez Escudero, Chil y Naranjo , Bethencourt Afonso , Alvarez Delgado, Anonimo Cedeño). This first channel is proposed to represent the first month (JuneJuly); the following carved channels (towards right hand side) would thus represent consecutively the 2 nd , 3rd, 4th, 5th and 6th months up to reaching Winter Solstice (Fig. 7 and 8, Discussion section). The apparent year sunrise arch would then start to go back and each following month, starting December-January that would be the $7^{\text {th }}$ 
Ancient Canarian month. All following months would be represented by each "Quesera" rock prominence strip: 7th, 8th, 9th, 10th, 11th, 12th months. Postulated months of Canarian year show the number of days, which are depicted in figures 7 and 8. Days add up in 365 total what would be a solar calendar similar to Egyptian one and others. In addition, a Lunar calendar is also represented and its complete analysis and calculations will be shown in another paper (unpublished). Thus, a lunisolar calend has been found, as it was proposed by Anónimo Cedeño (1682).

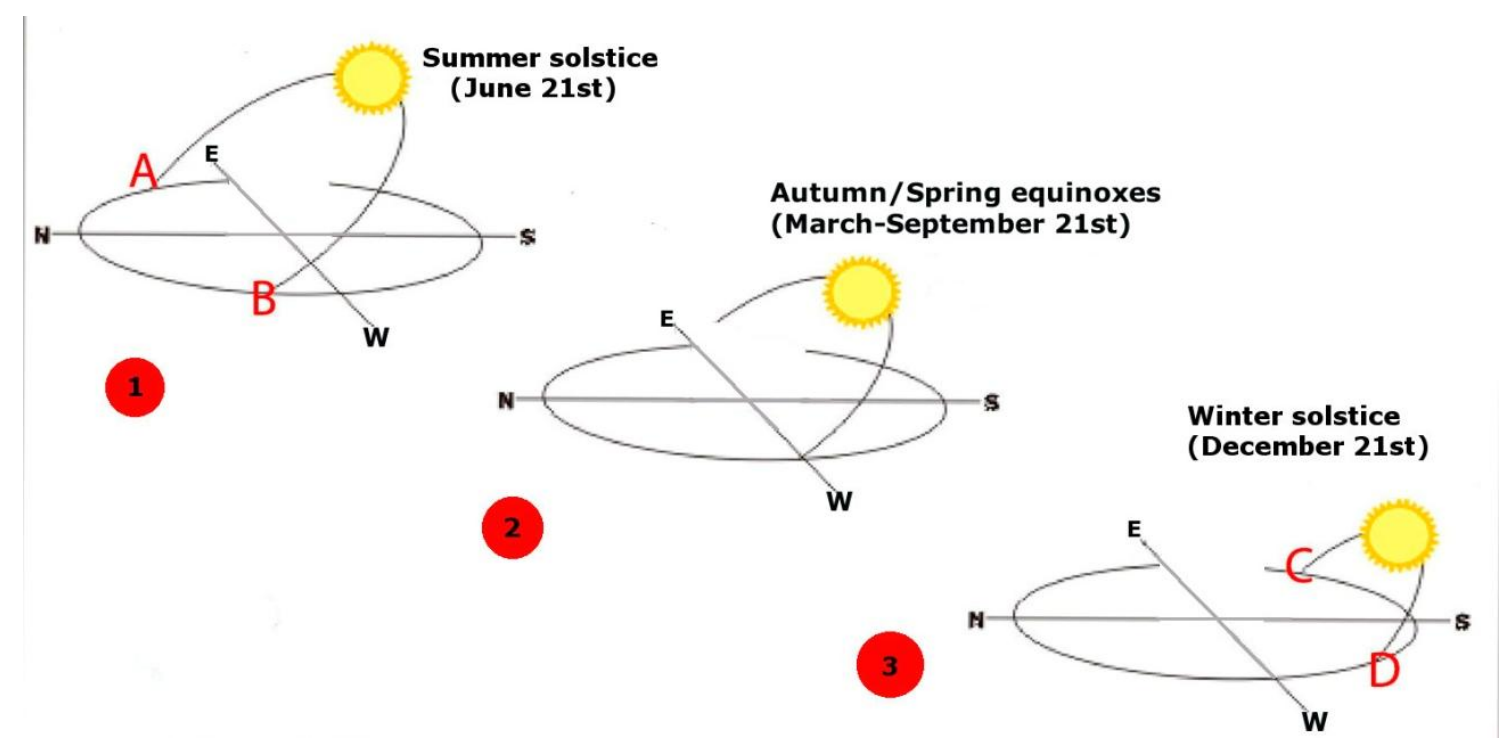

Fig. 5 Apparent Sun pathway on sky in northern Earth Hemisphere

Sun apparent way on sky observed from "Quesera" of Zorzamas. Sun reaches highest point on sky on Summer Solstice $\left(J u n e ~ 21^{\text {st }}\right.$ ) and follows the largest arch (A to B), it reaches a middle point in March and September 21 st (Equinoxes); these days Sun raises precisely at East point and sets at West point. The shortest arch is observed on Winter Solstice, December 21st.

\section{Discussion}

\section{Ancient Mediterranean / Atlantic and other calendars}

Several prehistoric structures have been proposed to be calendars: including megalithic and ceramic engravings. (Magli, 2016). Diverse megalithic paleolithic tools have been claimed to be calendars in Euro-Mediterranean-Atlanctic area (Magli, 2016) (Gofney et $a l$, 2013). Most ancient calendars are seen and thought to be based on lunar phases and their use was mainly for religions and ritual practices, not excluding some other 
usefulness. However, agricultural calendars for sowing and harvesting have been solar seasonal ones, which have coexisted with lunar calendars (Magli, 2016). Neolithic and megalithic archaeological constructions measuring year time equinoxes and solstices have also been described throughout world (Goffney et al, 2013).

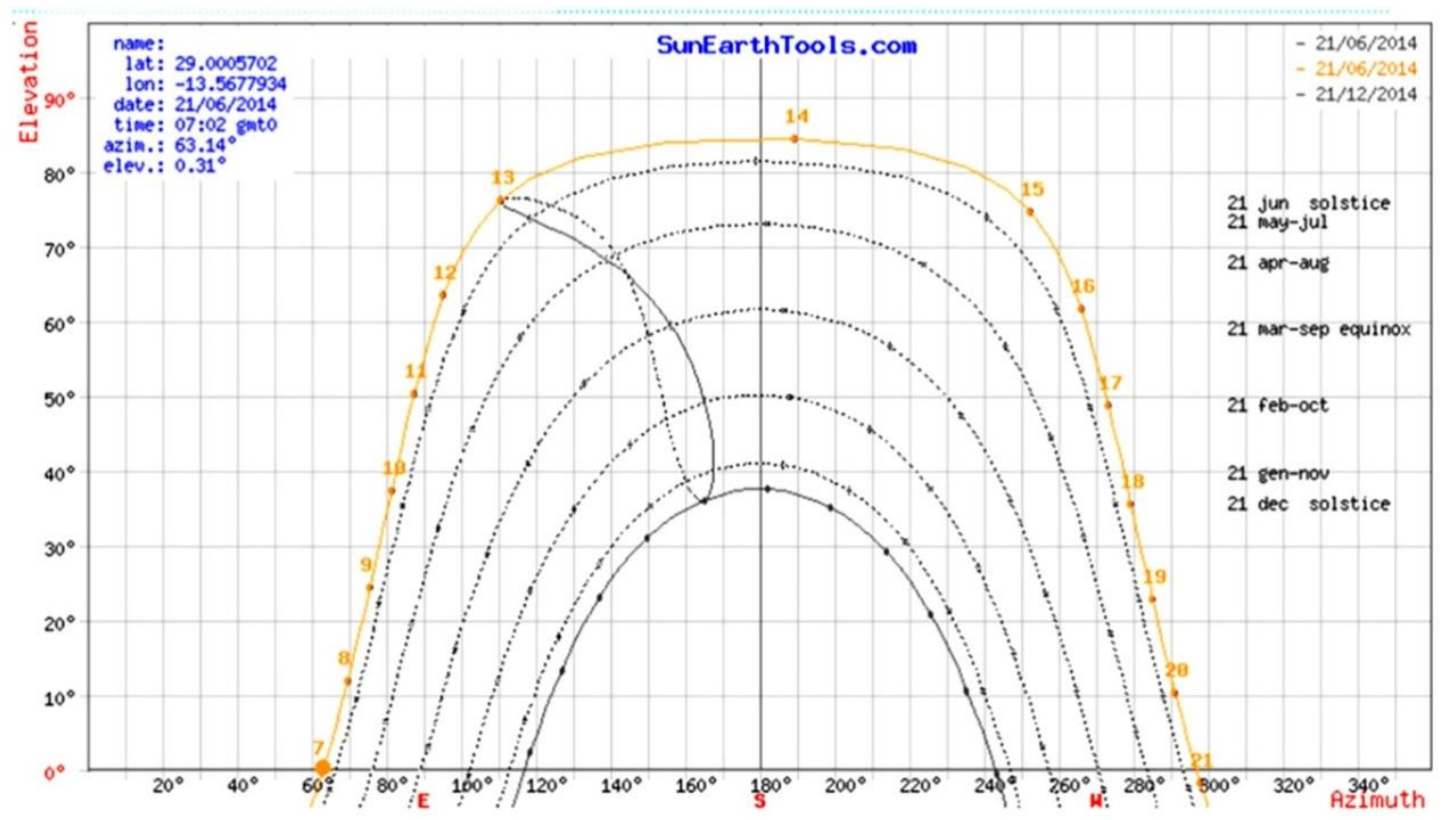

Fig. 6 Diagram which summarizes all daily observations from "Quesera" of Zonzamas sunrise: Azimuths and Elevations during time comprised between Summer and Winter Solstices

Sun Earth Tools online programme software constructs depicted arches with observed azimuths degrees at sunrise. It is observed that Summer Solstice sunrise azimuth is $62^{\circ}$; also it is seen that Winter Solstice sunrise azimuth is $117^{\circ}$. Then Sun apparently starts back towards Sping Equinox (Fig. 4). Sunsets Azimuths are also given by computer program. Sunset at Summer Solstice takes place at azimuth $306^{\circ}$; Sunset at Winter Solstice is $243^{\circ}$. Azimuths sunrises at Equinoxes are recorded and shown at $271^{\circ}$. This rising sun arch is more clearly seen in a photograph of landscape at Fig. 4. Sunrise follows the following loop for observer:

Summer Solstice $\longrightarrow$ Autumn Equinox $\longrightarrow$ Winte $\longrightarrow$ Summer Solstice

Regarding relatively more recent calendars, it seems that Babilonian and Persian (Iranian) calendars $(2,000$ years BC) were the first recorded ones as solar calendars, favoring it over a lunar one. Iranians used a 360 days solar calendar and 
12 months of 30 days which were divided according to lunar phases. They added one additional month every 6 years to synchronize seasons with calendar. The oldest recognized astronomical text come from Babylonia, but the system used is thought to stem from earlier Sumerian society. Although Sumerian calendar seems to have had 12 lunar months of 29 or 30 days (354 days with an extra month periodically added for Sun cycle connection) (Britannic Encyclopedia, 2008).

\section{Ancient Egyptian civil calendars}

It was a solar calendar with 365-days year, with 3 seasons (Flood, Growth and Low Water) and each 30 days month divided in decades (10 days) (it was used by about 2,510 years BC). This calendar was a quarter of a day shorter than the present solar year (Gregorian calendar). Some correction (not yet documented) may have periodically been done. Civil calendar was related with Sirius star raising, but it was not that precise and Sun calendar became widespread in Egypt. Sirius raised in Heliopolis between June-July since 3,500 years BC till 5th century AD.

This was a civil calendar; however, an Egyptian lunar calendar was also used in parallel for religions purposes. This lunar calendar was more ancient than solar calendar: and started with a new Moon phase. (Claget, 1989) (Britannic Encyclopedia, 2008).

\section{Greek, Roman, Julian, Gregorian calendars}

Greek calendar was first Moon based calendar with a 354-day year and 12 months of 29 or 30 days; periodical yearly corrections were done to keep up with Sun 365.242 days cycle. Several kind of calendars coexisted in Greek classical times in nowadays Greek and Turkey area. Most early Mediterranean civilizations started using 24 seasonal hours in the day (half for day and half for night). (Britannic Encyclopedia ,2008). Julian calendar (Julius Caesar, 46 year BC), had 365 days with 12 months for a year; one day was added in February each four years. It was a bit longer than the exact tropic calendar. Years later, Pope Gregory XIII introduced Gregorian calendar that it is nowadays used in most western World. Gregory XIII removed ten days from Julian calendar in October 1582 and also reduced year by about ten minutes. 


\section{Solar Year of ancient Canarians}

It is documented that ancient Canarians "Guanches" had a lunisolar calendar with 12th months, counting days by Sun and probably months by lunar phases,. Week had seven Sun days. Ancient Canarian year was named as a "Achano". (Anónimo de Cedeño, 1682). Beggining of ancient year started with Summer Solstice, around June 21st (Marín de Cubas, 1694). This author was also supported by others in that "Guanches" or ancient Canarian calendar started at Summer Solstice: Gomez Escudero, Chil y Naranjo, Betancourt Afonso, Alvarez Delgado and Anónimo de Cedeño among others. Thus, "Quesera" represents a solar calendar according to our results (and a Lunar one, see below) as stated by Anónimo de Cedeño, 1682, with months varying between 30 and 31 days but one of them is shorter than others: 28 days; the latter corresponds to the second month of our present day Gregorian calendar: February. It is the 3rd month after Winter Solstice in "Quesera" calendar (Fig. 8). The particular rock prominence strip representing this 3rd month had a conic salient (red spot at Fig. 8.) (Serra Rafols, 1942); it corresponds to February and conic vertical salient function was most probably to point out that this month representation had to undergo periodical corrections. For example, adding one day more each four years, reaching 29 days instead of 28 like in Julian and present day Gregorian calendar. This longer month resulted in a longer year ("Leap Year") that would have 366 days instead of 365. In this way calendar was adjusted by ancient Canarians who showed a high degree of advanced astronomical knowledge by probably adding a Leap Year each 4 years.

\section{Mixed lunisolar calendar}

This described basalt rock carved in Zonzamas is thus a solar calendar that can also go together with Moon phases cycles data and function as a Lunar calendar probably more useful for religious and ritual data than for sowing and harvesting (Agriculture Sun Calendar). Nuñez de la Peña, (1676) clearly stated that a Lunar calendar was used by "Guanches" or Canarian aborigines. Sun Earth Tools program was also giving data for Moon phases. These phases were recorded for 2014-2015 longer time. Moon phase cycles could be also assessed and a Lunar calendar could be constructed in Zonzamas "Quesera" that parallels with Sun calendar starting June 21st, Summer Solstice (unpublished data). This will be analyzed in a forth coming paper. 


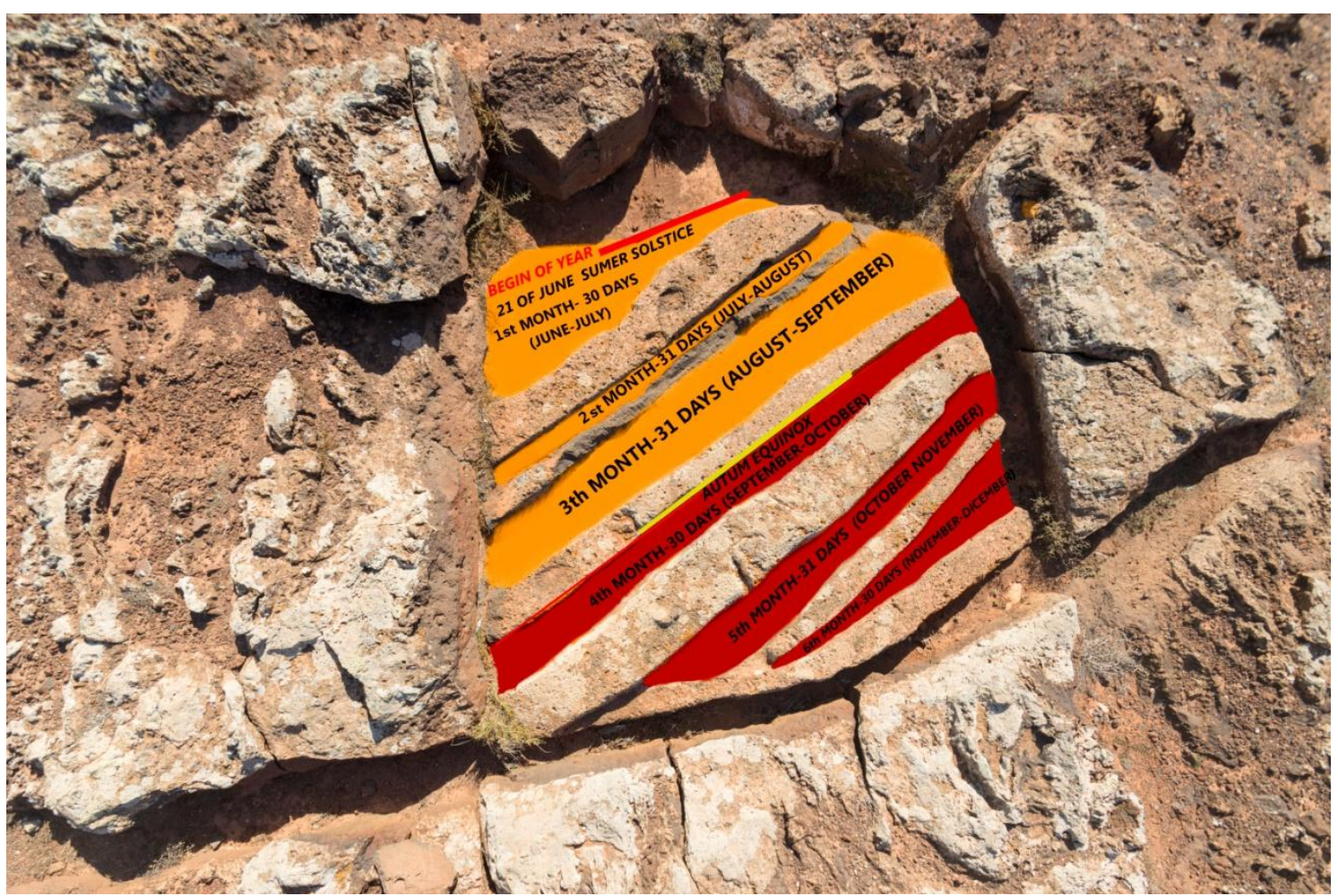

\section{Fig. 7 Zonzamas "Quesera" Sun calendar carved channels. A representation of first 6 months of Canarian year}

Upper left side 1st carved channel: this first cleft may also represent Tahiche mountain and starting coast and sea. Tahiche mountain is the point where Sun rises June 21st Summer solstice (Fig. 3 and 4).

Ancient canarian year, anthropology genetics and Iberian scripts in Lanzarote The Ancient Canarian year was named "Atxano “( Anónimo Cedeño, 1682) ( Nuñez de la Peña,1676). Atxano like many Canarian names may be traduced from Basque language, which is very similar to ancient Iberian language (Arnaiz-Villena, \& Alonso García, 2001). Atx, ats=stick, axis, hill; ano=shadow. It gives an idea that time maybe measured by an axis and the shadow (of Sun). They could probably connect a stick/axis/hill to a "Quesera" type calendar and take another kind of additional measurements. Stick shadow on "Quesera" would be pointing northwards and would be minimal at Summer Solstice, middle longitude at Equinox and largest one at Winter Solstice: otherwise stick shadow could have been useful even for constructing "Quesera" calendars. 


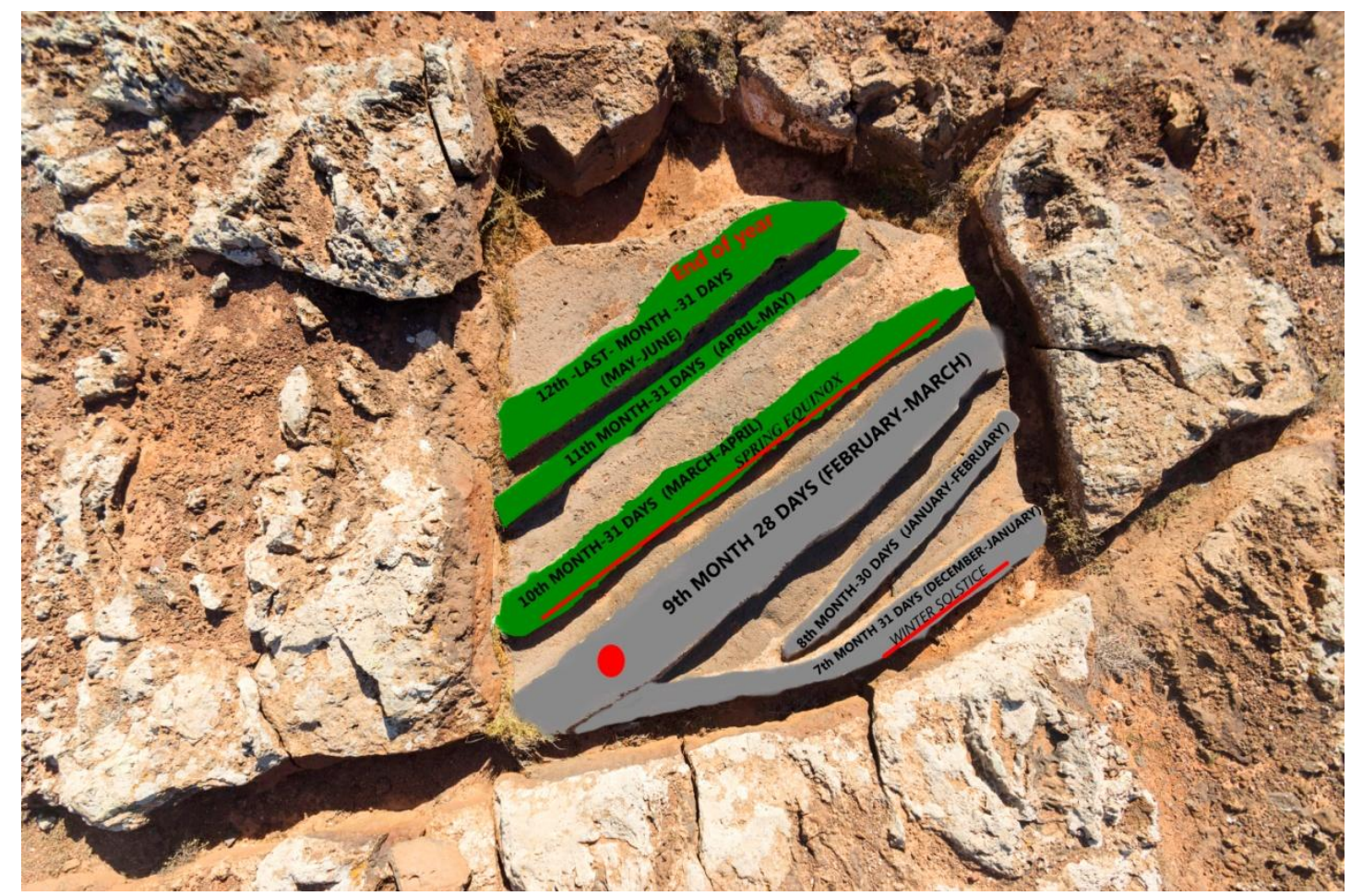

Fig. 8 Zonzamas "Quesera" Sun calendar rock prominent strips. Second 6 months From Winter Solstice (right) to left the rest of months are represented, reaching 12th months and a 365 days year. the conic rock salient (red spot) pointed out that this month (equivalent to February should have a time correction each 4 years by adding one day and becoming a 29 days month instead of a 28 days one. This "Leap Years" would have 365 days instead 365.

On the other hand, we have demonstrated that Iberian scripts are spread over Lanzarote and Fuerteventura Is. rocks and are more ancient than old Berber writing on rocks, because Berber scripts are placed over Iberian scripts in all cases (unpublished). The presence of mummification, pyramids and genetic data support that "Guanches" existed in Canary Islands thousands years ago (Arnaiz-Villena et al, 2015). Presence of megalithic carved rock channels (similar to the so called "cart-routes") in Lanzarote Island (unpublished) also put ancient Canarians as being a part of Atlantic/Mediterranean Bronze Age Megalithic culture (Ribeiro N, 2015), together with archaeology and ceramic studies in Lanzarote (Atoche et al, 2016; Sluys vd \& Gonzalez Artabe). Therefore, "Quesera" calendar is for us an Atlantic/Mediterranean Megalithic culture artefact and built long before Phoenician and Roman culture reached Canary Islands. 


\section{Acknowledgments}

We thank University Complutense from Madrid (Spain) for its support and the following colleagues who have been important for carrying out present work and conceiving and writing present paper: Julián Rodríguez Rodríguez, Antonio Jesús Montelongo Franquiz, María Antonia Perera Betancor, Máximino Álvarez Pérez, José Manuel Espinel Cejas, Ramón Alfonso Hernández, Jose R. Farray Barreto and Orlando Batista Aparicio. Also, we thank Valentín Ruiz-del-Valle by continuously pushing since several years ago about publishing abroad this "Quesera" prehistoric monument. Marianne Van der Sluys and Jesús Gonzalez Artabe were (and are) also important for spreading light in Lanzarote archaeology and their help is indebted. Finally it has been particularly important Adrián López Nares, who has put together in paper all pieces of this present research.

Conflicts of Interest: The authors declare no conflict of interest.

\section{References}

Anónimo Cedeño. (Antonio Cedeño?). 1682. Breve Resumen y Historia Verdadera de la Conquista de Canaria. Compilation and Edition by Barrios Garcia J. (2016-2017)

Arnaiz-Villena A., Muñiz E., Campos C., Gómez-Casado E., Tomasi S., MartínezQuiles N., Martín-Villa M., Palacio-Gruber J. 2015. Origin of Ancient Canary Islanders (Guanches): presence of Atlantic/Iberian HLA and Y chromosome genes and Ancient Iberian language. Int. J. Mod. Anthrop 8: 67-93.

Arnaiz-Villena A. \& Alonso García J. 2001. Egipcios, Bereberes, Guanches y Vascos. Ed. Visión Libros. (3rd Edition 2011) ACCI. Madrid (Spain).

Atoche Peña P. \& Ramirez Rodriguez MA. 2016. C14 References and Cultural Sequence in the Protohistory of Lanzarote (Canary Islands), Iber-Crono.Actas del Congreso de Cronometrias para la Peninsula Iberica, pp 272-285. Barcelona (Spain). Available at Research Gate. 
Barrios Garcia J. 2017. La Transmision Textual de la Cronica de la Conquista de Gran Canaria atribuida a Antonio Cedeño ,Anuario de Estudios Atlanticos. No.63: 063-002, Available at www.academia.edu

Braem H. 2010. Tras las huellas de los aborigenes. Ed. Zech Santa Ursula. Tenerife, Canary Islands (Spain).

Britannic Encyclopedia online. 2008. "Calendar" article.

Bogaard Pvd. Scientific reports 3, article 2107. 2013. The origin of the Canary Islands seamount province. New ages of old seamounts.

https://www.nature.com/articles/srep02107

Cabrera Perez JC. 1992. Lanzarote y los Majos. Ed. Litografía Romero. Santa Cruz de Tenerife, Canary Islands (Spain).

Claget M. 1989. Ancient Egyptian Science: calendars, clocks and astronomy. Ed. American Philosophical Society (3 vols). Philadelphia (USA).

Corrales C. \& Corbella D. 2013. Diccionario Histórico del Español en Canarias. Ed. Instituto de Estudios Canarios. Tenerife, Canary Islands (Spain).

Fanjul Peraza A. 2003. Megalitos en Marruecos. http://academia.edu.

Goffney V., Fitche S., Ramsey E., et al. 2013. Time and Place: A luni-solar "timereckover" from 8th millenium BC Scotland. Internet archaeology 34: https://doi.org/10.11141/xa.34.1

Magli G. 2016. Archaeoastronomy: introduction to the science of star and stones. Ed. Springuer International Publishing. Switzerland.

Marin de Cubas TA 1642. Historia de las Siete Islas de la Gran Canaria Ed. Principe. Transcripcion de F.Osorio Acevedo.Canarias Clasica. 1993. La Laguna, Tenerife, Islas Canarias (Spain)

Núñez de la Peña J 1676. Conquista.Antiguedades de las Islas de la Gran Canaria. Ed. Imprenta Real, Madrid (1676). Re-edited in 1847: Imprenta Isleña. Santa Cruz de Tenerife, Islas Canarias (Spain)

Parker RA. 1950. The calendar of Ancient Egypt. Ed. Chicago University Press. Chicago (USA). 
Paz-Sanchez M. \& Quintero Sanchez O. 2008. La historia de Canarias. Ed. Cabildo de La Palma. La Palma, Canary Islands (Spain).

Ribeiro N., Joaquinito A., Rodrigues Af., Azevedo MT. 2015. Achaeology and rock art of Macaronesia: New contributions. IV Encontro de Doutorandos e Post-Douorandos Macao.

Rugles CLN. \& Cotte M. 2010. Heritage sites in astronomy and archaeoastronomy in the context of the UNESCO World Heritage Convention: A Thematic Study. Paris (France).

Sluys Mvd \& Gonzalez Artabe J. 2017. Consideraciones tras el Estudio de la Ceramica Incisa de las Islas de Lanzarote y Fuerteventura. Ed. Authors, Pamplona (Spain)

Serra Rafols A. 1492. Crónica arqueológica visita de estudio a Lanzarote y Fuerteventura. Revista de Historia Canaria n58: 126-127.

To cite this article:

Marcial Medina, Antonio Arnaiz-Villena 2018. A Lunisolar Prehistoric Calendar in Lanzarote Island:

"La Quesera" (Cheeseboard) from Zonzamas

International Journal of Modern Anthropology. 2 (11): 147 - 161

DOI: http://dx.doi.org/10.4314/ijma.v2i11.7

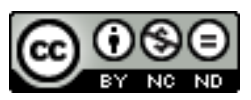

This article, as all articles published in this journal, is under The Creative Commons Attribution:

Attribution-NonCommercial-NoDerivatives 4.0 International (CC BY-NC-ND 4.0). https://creativecommons.org/licenses/by-nc-nd/4.0/ 